\title{
Influence of Integrated Supply of Bio Fertilizers, Chemical Fertilizers and Vermicompost on Soil Nutrient Status
}

\author{
Sushma Mishra*, Aruna Jain \\ Sarojini Naidu Govt.Girls P.G. College, Shivaji Nagar, Bhopal (M.P) \\ Corresponding Author: mishrasushma21@gmail.com
}

Copyright $@ 2013$ Horizon Research Publishing All rights reserved.

\begin{abstract}
The aims of this work were to evaluate the changes in soil properties with the application of bio fertilizers, chemical fertilizers, vermicompost and their combinations. The experiment was conducted in a randomized block design (RBD) with 8 treatments i.e. $\mathrm{T}_{1}-\mathrm{NT}$, $\mathrm{T}_{2}-\mathrm{VC}, \mathrm{T}_{3}-\mathrm{BF}, \mathrm{T}_{4}-\mathrm{CF}, \mathrm{T}_{5}-\mathrm{BF}+\mathrm{VC}, \mathrm{T}_{6}-\mathrm{BF}+\mathrm{CF}, \mathrm{T}_{7}-\mathrm{CF}+\mathrm{VC}$, $\mathrm{T}_{8}-\mathrm{BF}+\mathrm{CF}+\mathrm{VC}$. The increased value in $\mathrm{N}, \mathrm{P}, \mathrm{K}, \mathrm{OC}, \mathrm{pH}$ and EC was $281 \mathrm{~kg} / \mathrm{ha}, 20.2 \mathrm{~kg} / \mathrm{ha}, 296 \mathrm{~kg} / \mathrm{ha}, 0.69 \%, 7.7\left(\mathrm{~T}_{7}\right.$ plot), $0.21 \mathrm{dsm}^{-1}$ respectively, in $\mathrm{T}_{8}$ plot compared to non-treated soil. However, before sowing, soil N, P, K, OC, $\mathrm{pH}$ and $\mathrm{EC}$ was $260 \mathrm{~kg} / \mathrm{ha}, 18.80 \mathrm{~kg} / \mathrm{ha}, 281 \mathrm{~kg} / \mathrm{ha}, 0.52 \%$, $6.8,0.48 \mathrm{dsm}^{-1}$ which was far less than the nutrients obtained in the soil after harvest. After the analysis of nutrient status in post harvest soil it can be concluded that INM in soil by combined application of $\mathrm{BF}+\mathrm{CF}+\mathrm{VC}\left(\mathrm{T}_{8}\right.$ plot $)$ are best for soil fertility for longer periods. Based on the results of the current study, it is clear that by use of INM we can minimize the quantity of fertilizer and recycle the farm waste, thus make safe environment and sustainable soil fertility.
\end{abstract}

Keywords Soil Properties, NPK, OC, EC, INM

\section{Introduction}

Soils are the natural medium for growth of the plants. Plants obtain mineral and nutrients from the soil. Long-term field experiments on nutrient management in different cropping system indicated decline in factor productivity with soil organic matter as well as available N, P and K status of the soil. Besides, the physico- biochemical properties of the soil damaged significantly. Presently, Indian soils are $70 \%$ deficient in $\mathrm{N}, 50 \%$ in $\mathrm{P}, 13 \%$ in $\mathrm{K}, 4.7 \%$ in $\mathrm{Zn}, 4.8 \%$ in $\mathrm{Cu}$, $11.5 \%$ in $\mathrm{Fe}$ and $4.0 \%$ in Mn [M. S. Pal, 2007]. The chemical fertilizers are becoming costlier day by day due to escalating costs and scarce availability of commodities. The use of organic farming with organic amendments to soil as nutrient inputs is increasing and it is an alternative agricultural practice for sustaining economically viable crop production with minimal environmental pollution (Padel, S.,2009). The productivity of a soil depends on such things as its chemical composition and porosity, its content of air and water, and its temperature. It is bridge between the inorganic, organic and living worlds.

\section{Material and Methods}

The experiment was conducted in a randomized block design (RBD) with 8 treatment using chemical fertilizers (NPK), vemicompost, and biofertilizers ( Azotobacter, phosphate solubilizing bacteria) in different combinations including one control treatment. The treatments were $\mathrm{T}_{1}$ control (no treatment), $\mathrm{T}_{2}$-Vermicompost $5 \mathrm{t} \mathrm{ha}^{-1}, \mathrm{~T}_{3}$ Biofertlizers (250g Azotobacter ha $\left.{ }^{-1}+250 \mathrm{~g} \mathrm{PSB} \mathrm{ha}^{-1}\right), \mathrm{T}_{4}$ - $^{-}$ Chemical fertilizers ( 60:30:30 $\left.\mathrm{kg} \mathrm{NPK} \mathrm{ha}^{-1}\right), \mathrm{T}_{5} \mathrm{BF}+\mathrm{VC}$ $\left(125 \mathrm{~g}\right.$ Azotobacter $+125 \mathrm{~g}$ PSB $+5 \mathrm{t}$ vermicompost $\left.\mathrm{ha}^{-1}\right)$, $\mathrm{T}_{6}-\mathrm{BF}+\mathrm{CF}[125 \mathrm{~g}$ Azotobacter $+125 \mathrm{~g}$ PSB $+50 \% \mathrm{NPK}$ ( $\mathrm{RDF}$ ) ha $\left.\mathrm{h}^{-1}\right], \mathrm{T}_{7} \mathrm{CF}+\mathrm{VC}$ ( $50 \% \mathrm{NPK}+5 \mathrm{t}$ vermicompost $\left.\mathrm{ha}^{-1}\right)$ and $\mathrm{T}_{8}-\mathrm{BF}+\mathrm{CF}+\mathrm{VC}[250 \mathrm{~g}$ biofertilizers $(125 \mathrm{~g}$ Azotobacter $+125 \mathrm{~g}$ PSB $)+50 \%$ NPK ( RDF $)+5$ t VC.

The $\mathrm{pH}$ of soil was determined using Equiptronics $\mathrm{pH}$ meter as described by Jackson (1967). The EC of the soil samples was determined on an Equiptronic's digital EC Bridge. The available nitrogen was estimated by Microkjeldahl method (Mishra, 1968). Available phosphorus, available potassium and organic carbon of the soil were estimated by the method of Jackson (1967).

\section{Statistical Analysis}

Analysis of observation taken on different variable was carried out to know the degree of variation among all the treatments. The results were obtained through analysis of variance (ANOVA) and SPSS software, version 20, 2011.

\section{Result and Discussion}

Abbreviations:- NT- No Treatment, BF-Biofertilizers, CF- Chemical fertilizers, VC- Vermicompost, SD- Standard Deviation, SEm- Standard Error mean, SA-Statistical 
Analysis, PSB-Phosphorus Solubilizing Bacteria, NNitrogen, P- Phosphorus, K- Potassium, EC- Electrical Conductivity, OC- Organic Carbon, INM- Integrated Nurient Management, df- degree of freedom.

Soil samples were analyzed before sowing and after the harvesting crop to visualize the amount of major and micronutrients remaining in the soil and that all nutrients were significantly affected by different treatments. N, P, K, and $\mathrm{OC}$ were maximum under combined application of organic and inorganic nutrients in $\mathrm{T}_{8}$ plot after harvest. The increased value in $\mathrm{N}, \mathrm{P}, \mathrm{K}, \mathrm{OC}, \mathrm{pH}$ and $\mathrm{EC}$ was $281 \mathrm{~kg} / \mathrm{ha}$, $20.2 \mathrm{~kg} / \mathrm{ha}, 296 \mathrm{~kg} / \mathrm{ha}, 0.69 \%, 7.7$ ( $\mathrm{T}_{7}$ plot), $0.21 \mathrm{dsm}^{-1}$ respectively (Table 2.), in $\mathrm{T}_{8}$ plot compared to non-treated soil. However, before sowing, soil N, P, K, OC, pH and EC was $260 \mathrm{~kg} / \mathrm{ha}, 18.80 \mathrm{~kg} / \mathrm{ha}, 281 \mathrm{~kg} / \mathrm{ha}, 0.52 \%, 6.8,0.48$ $\mathrm{dsm}^{-1}$ (Table 1.) which was far less than the nutrients obtained in the soil after harvest.
Higher availability of N, P, K, OC, pH after harvesting the crop under combined application of nutrients i.e. $(\mathrm{BF}, \mathrm{CF}$, VC) may be due to improved physical, chemical and biological properties on account of organic matter addition, as already observed by Marinari S. et al., (2000); Mahmoud EK and Mahmoud Ebrahim (2012); Anwar et al., (2005); Dauda et al., (2008); Patra et al.,(2000); Chand et al., (2011) on Soil.

After the analysis of nutrient status in post harvest soil it can be concluded that INM in soil by combined application of $\mathrm{BF}+\mathrm{CF}+\mathrm{VC}\left(\mathrm{T}_{8}\right.$ plot $)$ are best for soil fertility for longer periods. By use of INM we can minimize the quantity of fertilizer and recycle the farm waste, thus make safe environment and sustainable soil fertility and crop quality. INM will increase soil organic matter status, which act as a reservoir for nutrients and hence improve soil physico-chemical attributes of plant growth.

Table 1. Chemistry of Soil before sowing

\begin{tabular}{|c|c|c|c|c|c|c|c|}
\hline S. No. & Sample & $\mathrm{pH}$ & $\mathrm{OC} \%$ & $\mathrm{EC}\left(\mathrm{dsm}^{-1}\right)$ & Available N in kg/ha & Available P in kg/ha & Available $\mathrm{K}$ in kg/ha \\
\hline 1. & Soil & 6.8 & 0.52 & 0.48 & 260 & 18.80 & 281 \\
\hline
\end{tabular}

Table 2. Effect of INM on Soil Chemistry after harvesting crop

\begin{tabular}{|c|c|c|c|c|c|c|c|}
\hline Plot No. & Treatment in soil & $\mathrm{pH}$ & $\mathrm{OC} \%$ & $\begin{array}{c}\text { EC } \\
\left(\mathrm{dsm}^{1}\right)\end{array}$ & $\mathrm{N}$ in $\mathrm{kg} / \mathrm{ha}$ & $\mathrm{P}$ in $\mathrm{kg} / \mathrm{ha}$ & $\mathrm{K}$ in $\mathrm{kg} / \mathrm{ha}$ \\
\hline $\mathrm{T}_{1}$ & NT & 7.5 & 0.43 & 0.32 & 258 & 14.8 & 271 \\
\hline $\mathrm{T}_{2}$ & $\mathrm{VC}$ & 7.2 & 0.62 & 0.26 & 278 & 19.7 & 292 \\
\hline $\mathrm{T}_{3}$ & $\mathrm{BF}$ & 7.4 & 0.60 & 0.27 & 274 & 18.6 & 289 \\
\hline $\mathrm{T}_{4}$ & $\mathrm{CF}$ & 7.6 & 0.51 & 0.29 & 269 & 17.18 & 284 \\
\hline $\mathrm{T}_{5}$ & $\mathrm{BF}+\mathrm{VC}$ & 7.1 & 0.67 & 0.24 & 280 & 20.12 & 294 \\
\hline $\mathrm{T}_{6}$ & $\mathrm{BF}+\mathrm{CF}$ & 7.4 & 0.49 & 0.31 & 263 & 16.1 & 276 \\
\hline $\mathrm{T}_{7}$ & $\mathrm{CF}+\mathrm{VC}$ & 7.7 & 0.50 & 0.30 & 268 & 16.8 & 280 \\
\hline $\mathrm{T}_{8}$ & $\begin{array}{c}\mathrm{BF}+\mathrm{CF}+ \\
\mathrm{VC}\end{array}$ & 7.3 & 0.69 & 0.21 & 281 & 20.2 & 296 \\
\hline
\end{tabular}

Table 3. Statistical Analysis of Soil Chemistry after harvesting

\begin{tabular}{|c|c|c|c|c|c|c|c|}
\hline \multicolumn{2}{|c|}{ Parameters } & $\mathrm{pH}$ & $\mathrm{OC}$ & $\mathrm{EC}$ & $\mathrm{N}$ & $\mathrm{P}$ & $\mathrm{K}$ \\
\hline \multicolumn{2}{|c|}{ Mean } & 7.31 & 0.56 & 0.2750 & 271.37 & 17.9375 & 285.25 \\
\hline \multicolumn{2}{|c|}{ Variation } & 0.04125 & 0.008855 & 0.0014 & 69.125 & 4.07365 & 81.3571 \\
\hline \multicolumn{2}{|c|}{ SD } & 0.203 & 0.094 & 0.374 & 8.314 & 2.01 & 9.0198 \\
\hline \multicolumn{2}{|c|}{ SEm } & 0.071 & 0.03327 & 0.01323 & 2.9394 & 0.71359 & 3.1889 \\
\hline \multicolumn{2}{|c|}{ t-value } & 101.83 & 16.944 & 20.788 & 92.320 & 25.13 & 89.44 \\
\hline \multicolumn{2}{|c|}{ df } & 7 & 7 & 7 & 7 & 7 & 7 \\
\hline \multicolumn{2}{|c|}{ Sig. (2 tailed) } & 0.000 & 0.000 & 0.000 & 0.000 & 0.000 & 0.000 \\
\hline \multirow{2}{*}{$\begin{array}{l}95 \% \text { confidence } \\
\text { interval of the } \\
\text { difference }\end{array}$} & Lower & 7.1427 & 0.4851 & 0.2437 & 264.42 & 16.2501 & 277.709 \\
\hline & Upper & 7.4823 & 0.6424 & 0.3063 & 278.325 & 19.624 & 292.790 \\
\hline
\end{tabular}




\section{Recommendation}

Plant and crop physiologists, microbiologists and agronomists agree that plant growth and development strictly depends on biological fertility factors. Long term studies on organic fertilizers and manures along with chemical fertilizers need to be initiated to develop integrated nutrient management schedule for obtaining good quality soil which is very important factor for surviving plant life.

\section{REFERENCES}

[1] Anwar M., D.D. Patra, S. Chand, A. Kumar, A.A. Naqvi and S.P.S. Khanuja. (2005). Effect of organic manure and inorganic fertilizer on growth, herb and oil yield, nutrient accumulation and oil quantity of French Basil. Communication in soil Science and plant analysis. 36: 1737-1739.

[2] Chand Sukhmal, Ankit Pandey, Mohammed Anwar and Dharni Dhar Patra (2011). Influence of integrated supply of vermicompost, bio fertilizer and inorganic fertilizer on productivity and quality of rose scented Geranium (Pelargonium Sp.). Indian J. of Natural Products and resources. Vol. 2(3): 375-382.

[3] Dauda S.N., F.A. Ajayi and E. Ndor (2008). Growth and yield of Watermelon (Citrullus lanatus) as affected by poultry manure application. Journal of Agriculture and Social
Science. 4: 121-124.

[4] Jackson ML. (1967). Soil Chemical analysis. Prentice Hall of India, Pvt. Ltd., New Delhi: 498.

[5] Mishra R. (1968). Ecology work book - Oxford and IBH Publishing Co. New Delhi.

[6] Mahmoud E.K. and M.M. Ibrahim. (2012). Effect of vermicompost and its mixtures with water treatment residuals on soil chemical properties and Barley growth. Journal of soil Sciences and plant nutrition. 12 (13). pp. 431-440.

[7] Marinari S., G. Masciandro, B. Ceccant, S. Grero. (2000). Influence of organic and mineral fertilizers on soil biological and physical properties. Bioresources Technology. 72: 9-17.

[8] Pal, M. S. (2007) "Integrated Plant Nutrient Management for Sustainable Crop Production" International Conference on 21st Century Challenges to Sustainable Agri-Food Systems Biotechnology, Environment, Nutrition, Trade and Policy, Bangalore (India), pp 335-346.

[9] Padel, S., Rocklinsberg, H. and Schmid, O. (2009). The implementation of organic principles and values in the European regulation for organic food. Food Policy $34: 245-251$.

[10] Patra D.D., M. Anwar and S. Chand (2000). Integrated nutrient management and waste recycling for restoring soil fertility and productivity in Japanese Mint (Mentha arvensis) and Mustard (Brassica juncea) sequence in Uttar Pradesh, India. Agric. Ecosys. and Environ., 80: 267-275.

[11] Statistical analysis. (2011).SPSS software, version 20. 